UDC 001.53

\title{
Computer Science in Transcaucasia and Baltic States: a Comparative Bibliometric Analysis
}

\author{
Shushanik A. Sargsyan ${ }^{1,2}$ and Edita G. Gzoyan ${ }^{1}$ \\ ${ }^{1}$ Center for Scientific Information Monitoring and Analysis (CSIAM) \\ Institute for Informatics and Automation Problems of NAS RA \\ ${ }^{2}$ Yerevan State Medical University after Mkhitar Heratsi, Medical Physics Department \\ e-mail: shushanik@ipia.sci.am
}

\begin{abstract}
Based on the Web of Science, InCites database, this article will analyze the publication output of the Transcaucasia and Baltic states in computer science research field, their citations, as well as international collaboration in the field of computer science. The obtained results demonstrate that publications on computer science from the Baltic states are nearly 4 times higher than publications from Transcaucasia. Among the Baltic states, Lithuania holds a primary position followed by Estonia and Latvia; while in the Transcaucasia, the leading position is held by Azerbaijan, and followed by Armenia and Georgia. The same picture can be seen in the case of citations on the works on computer science of the studied states.

In the international collaboration framework, the European states are the most frequent collaboration countries of the Baltic States. The same tendency can be seen in the case of Georgia and Armenia, while Azerbaijan shows a dramatically different vector of scientific internationalization.
\end{abstract}

Keywords: Computer science, Transcaucasia, Baltic states, Web of Science; InCites, citations, Bibliometric analysis, Regional analysis.

\section{Introduction}

The collapse of the Soviet Union resulted in the major transformations of the political map of the Eurasian continent. Despite sharing historical, economic, social and other similarities during the Soviet period, the 15 republics established as a result of the Soviet breakup, chose separate ways of political, social, economic, as well as scientific development. Already in 2004, all three Baltic states (Latvia, Lithuania, and Estonia) entered the European Union, while for a considerable time the Transcaucasia region (Armenia, Azerbaijan and Georgia) remained pro-Russian. Recently, however, there has also been some shift in the geopolitical discourse of Transcaucasia: Georgia also took a course to Europe, while Armenia chose to become a member-state of the Eurasian 
Economic Union. Azerbaijan holds a neutral position, maintaining close political ties with Turkey. Having all these developments in the background, the aim of this article is to analyze the development of computer science in the studied states, to understand the vectors of their international collaboration.

This article will present a bibliometric analysis of publications and citations in the field of computer science in the Transcaucasia and the Baltic states after their independence, their international collaboration, comparatively analyzing their scientific output in the field under study. Although already well-established computer science is a relatively new and dynamically developed research field, nowadays, it is a highly interdisciplinary scientific field that has significant links with mathematics, physics, biology and even humanities. The field is also declared a priority in the Baltic and Caucasus states. During the Soviet time, the studied countries had research institutions that were engaged in computer science. In 1958, Nikita Khrushchev announced the importance of cybernetics for defense and space industry. In furtherance of this, a lot of researchers from the Soviet Union were reeducated. Lithuanian researchers were the most active in the Baltic states. They established a computer plant in Vilnius - Sigma - where the major computing equipment was developed for non-military use. The Ruta 110 computer was designed and produced in "Sigma" and was widely used in the Soviet Union [1]. In the Caucasus region, major developments in this field occurred in Armenia, which was the "Silicon Valley" in the field of IT for the Soviet Union. In 1956, the Yerevan Computer Research and Development Institute was established as a pioneer in the IT and software industry in Soviet Armenia. In 1963, the Institute developed the Nairi computer for engineering purposes.

Another IT research hub was established in 1957 initially as the Computer Centre, which later became the Institute for Informatics and Automation Problems of NAS RA. The Institute also played a great role in the fields of computer science and its applications.

\section{Data and Method}

The study is based on the Clarivate Analytics' Web of Science InCites dataset. Publications from Armenia, Republic of Georgia, Azerbaijan, Lithuania, Latvia and Estonia were used for this analysis. The study period is 1991-2018, that is, after the establishment of their independence from the Soviet Union. The last update of the data was made on 04.02.2019. We took the Computer Science research area with the following sub-areas from the WOS: Artificial Intelligence, Cybernetics, Hardware \& Architecture, Information Systems, Interdisciplinary Applications, Software Engineering and Theory \& Methods.

The following types of documents were used in the article: Articles, Meeting Abstracts, Note, Proceedings Papers and Reviews.

For the purposes of our article, the full counting method was used, so that every participatory country receives a full count - for each article 1 score is assigned to each co-author country. Thus, some scientific products are counted more than once.

\section{Discussion}

In the period 1991-2018, the 6 Baltic and Caucasus countries considered here produced a total of 7721 computer science publications in the WOS Core Collection as detailed in Table 1. Among the countries studied, the Baltic states are in a leading position by the gross number of publications. The share of publications within the countries of the studied blocks is interestingly 
nearly the same: the three Baltic states have somewhat nearly two thousand publications, while the number of publications from the Caucasus states doesn't exceed 500.

Table 1: Gross number of publications from the individual Baltic and Transcaucasia states. WOS CC (1991-2018).

\begin{tabular}{|l|c|}
\hline \multicolumn{1}{|c|}{ Country } & Publications \\
\hline Lithuania & 2702 \\
\hline Estonia & 2075 \\
\hline Latvia & 1813 \\
\hline Azerbaijan & 516 \\
\hline Armenia & 344 \\
\hline Republic of Georgia & 312 \\
\hline
\end{tabular}

As can be seen from Table 1, Lithuania is by far the most productive country, whose publications are approaching 3 thousands, followed by Estonia and Latvia. Among the Caucasus states Azerbaijan has a leading position, while Armenia and Georgia have somewhat similar number of publications.

Fig. 1 shows the distribution of publications of the concerned countries by years. The figure shows the overall increase in the number of publication in all 6 countries, while in the case of the Baltic states this growth is quite obvious after 2004, which is the year of accession of the Baltic states to the EU, which presumably was the reason for the raise of publications from the Baltic states.

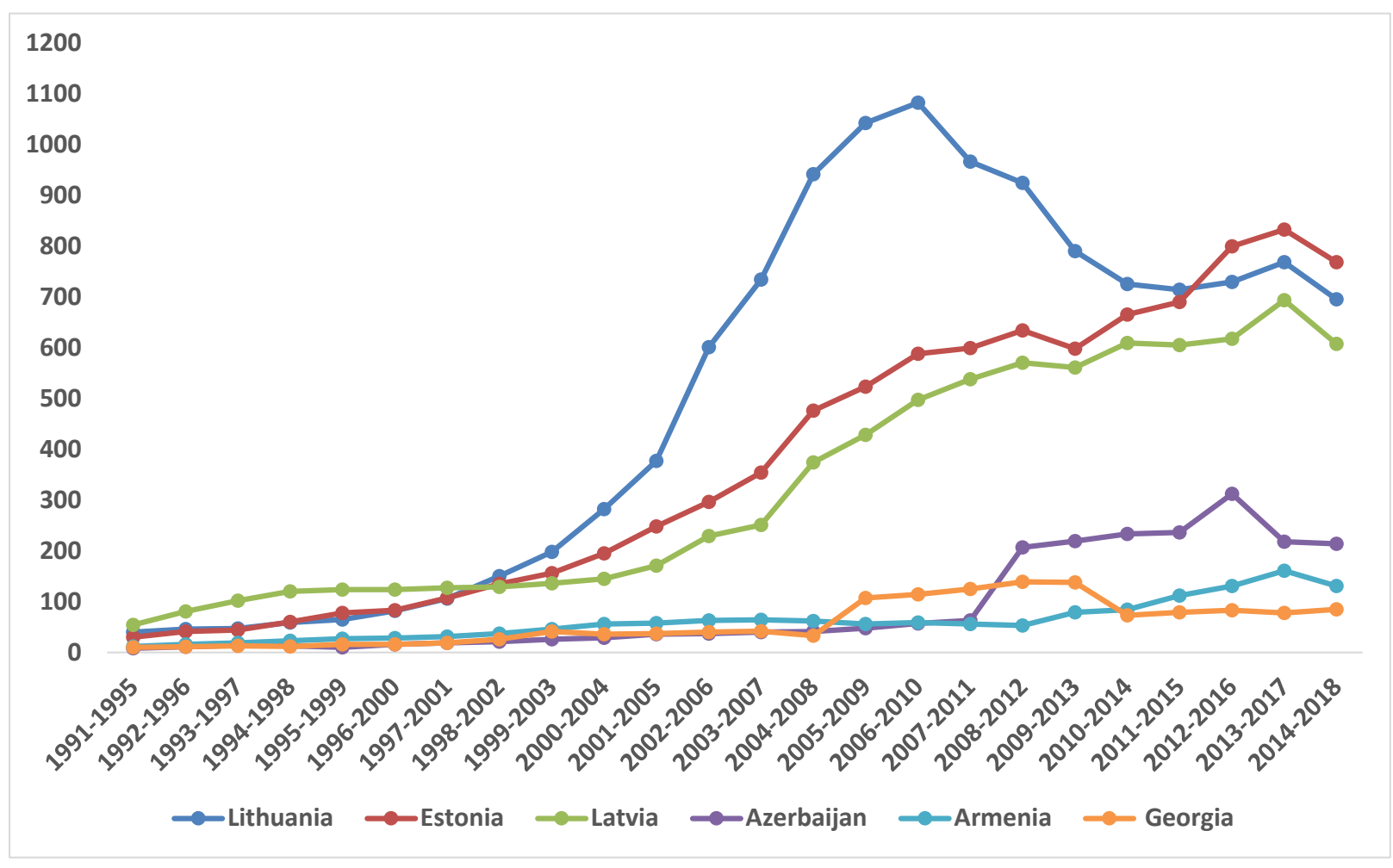

Fig. 1: Publications of the Baltic and Transcaucasia states from the WOS in 5 years trends (1991-2018). 
In the next part of our research, we looked into the number of citations received by the 6 countries studied. We have the same picture as with the publications. In the Baltic states the leading role is ascribed to Lithuania, followed by Estonia and Latvia. Among the Caucasus states, Azerbaijan is on the forefront, followed by Armenia and Georgia. This implies that together with the quantitative element, the publications of Baltic states are cited more. The quantity-citation link is seen also at the country level in Fig. 2.

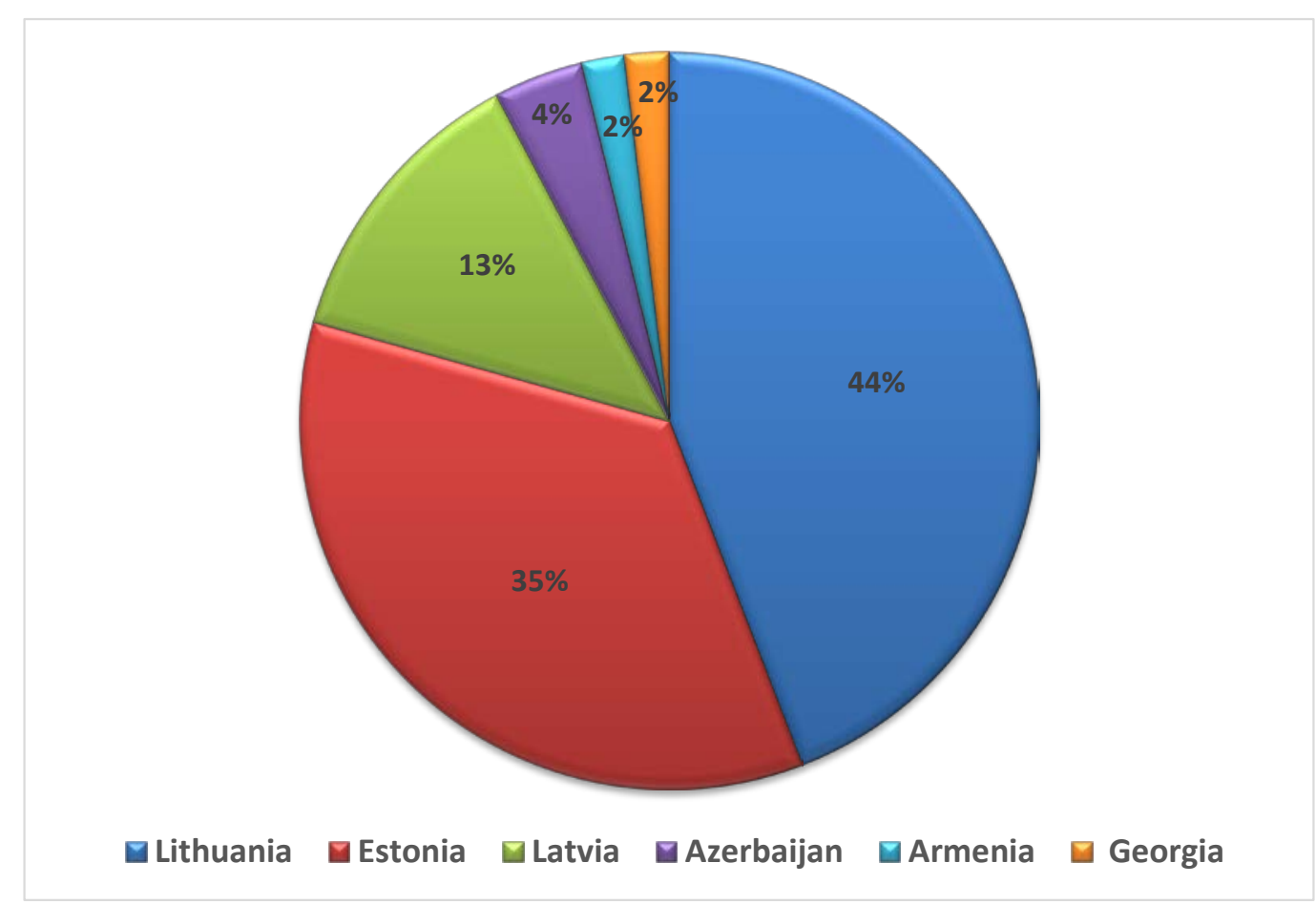

Fig. 2: Citations received by the publications of the Baltic and Transcaucasia states from the WOS (1991-2018).

\subsection{Scientific Collaboration of the Baltic and Caucasus States in the Field of Computer Science}

Scientific collaboration became one of the identifying features of modern science. It has become an important tool to promote science and technology, increase scientific output, as well as its visibility and impact of scientific collaboration. Of course, not all research collaboration ends up with a joint paper, especially in the field of computer science, where the result of collaboration can be a new computer program that is still considered to be the best indicator of scientific cooperation. There are different measurements of research collaboration [2], but for the purposes of our study we have chosen the co-authorship measurement method. Co-authorship is a complex phenomenon and it is built on several decisions at both state and individual levels. At the state level, scientific cooperation is influenced by the policy priorities of the states, which are reflected in scientific cooperation agreements with individual countries or a block of countries. At the individual level, the decision of individual scientists matters. The level of international coauthorship also depends on the size of the particular country, the "proximity" between the countries [3]. Meanwhile, the proximity is also a multi-layered phenomenon and includes the 
geographical position of the states, historical, cultural ties, linguistic affinity, and political, economic factors. Thematic proximity is another base for a collaboration decision [4]. All the mentioned factors can affect the collaboration decisions of individual scientists.

Taking this in the background, we studied the international scientific collaboration of the 6 countries concerned to find the preferences (Fig. 3).

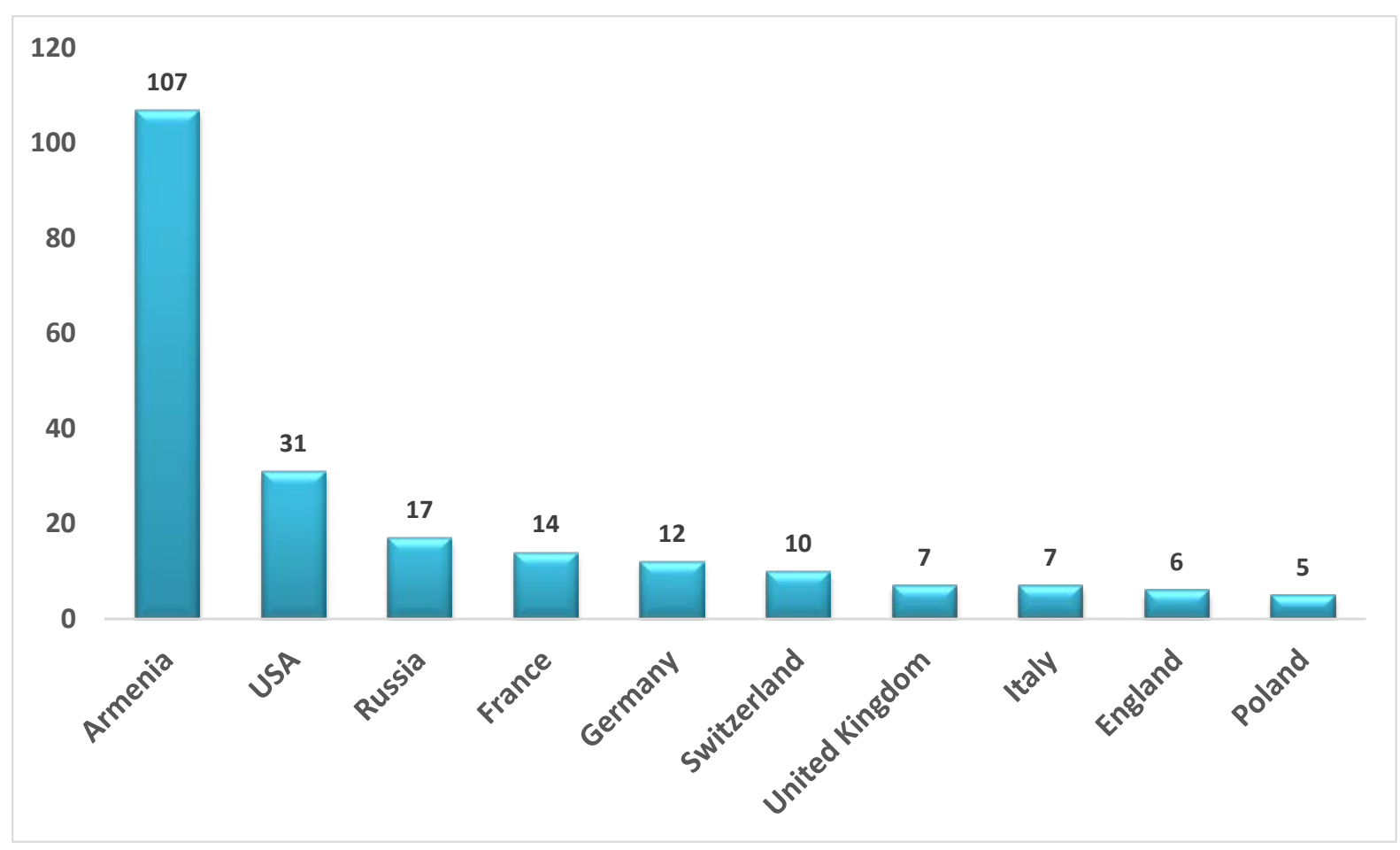

Fig. 3: Collaboration of Armenia in the field of computer science.

Fig. 3 presents the international scientific collaboration of Armenia in the researched field. It is evident that the great portion of papers is an inter-country collaboration, which are the joint publications of Armenian institutions. As we can see from the figure, USA is the main partner of Armenia in the field of computer science, followed by Russia and France. Fig. 3 also shows that the remaining collaboration states are from Europe. So, the Western direction is quite obvious in case of Armenia. Collectively, the European countries are the main partners of Armenia in computer science (61 publications). 


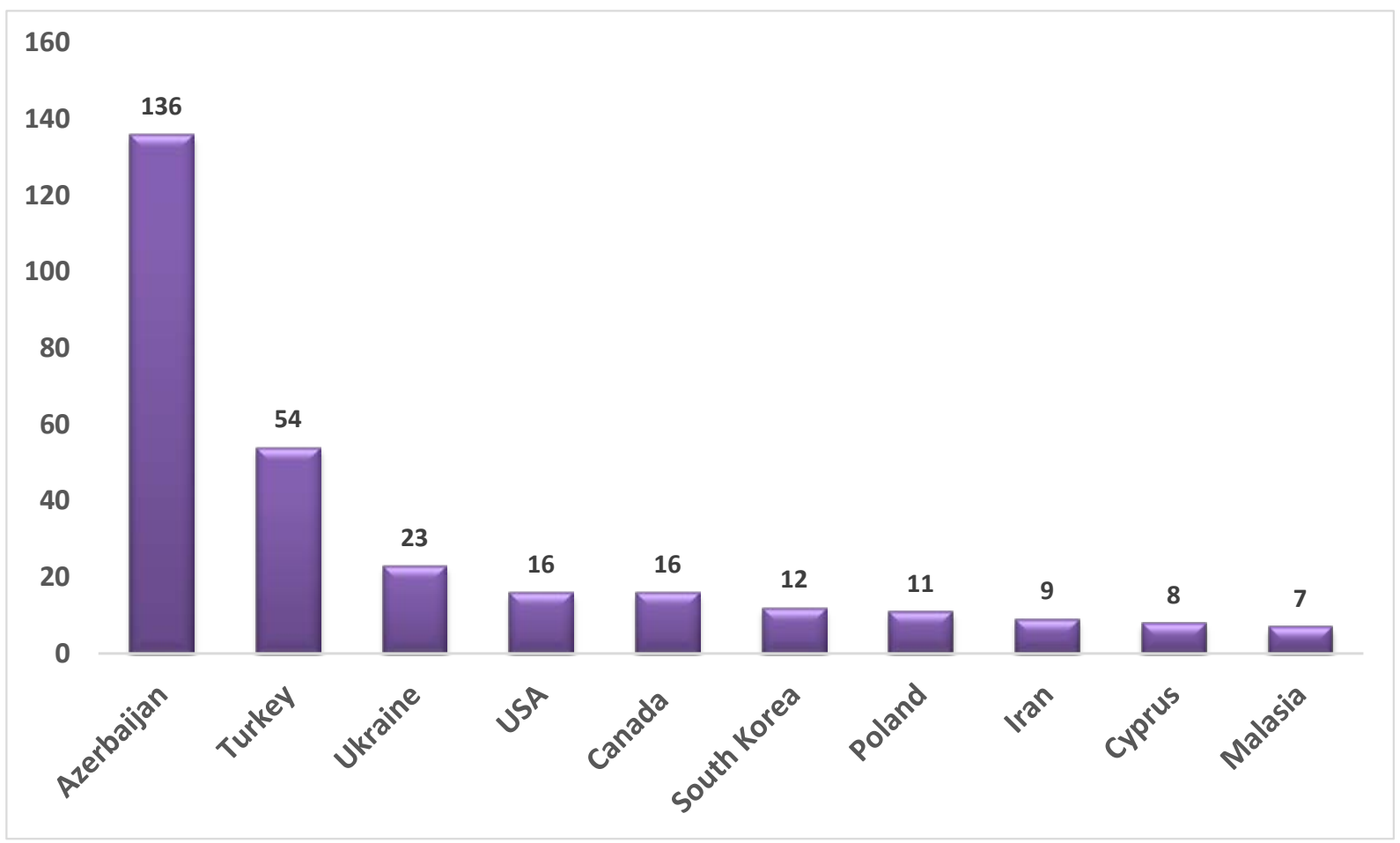

Fig. 4: International collaboration of Azerbaijan in the field of computer science.

International scientific collaboration of Azerbaijan showed a quite different pattern (see Fig. 4). Although here again the USA is among the first three main collaboration countries of Azerbaijan, the first partner of Azerbaijan is Turkey, with which Azerbaijani scientists have 54 joint publications in the field of computer science. Interestingly, Azerbaijan has quite passive links with Russia, and the republic hasn't accepted the European direction. Among the EU countries there is collaboration only with Poland and Cyprus. Meanwhile, Azerbaijan is actively cooperating with Canada, which appeared the fifth in the list of collaborative countries, and has some joint publications with South Korea and Malaysia. In case of Armenia and Georgia, these three countries are absent from the list of collaborating countries. Among the three Caucasus republics, Azerbaijan has the most publications in the WOS without international collaboration (136), which implies that their leading position among the other Caucasus states is not the result of collaboration. 


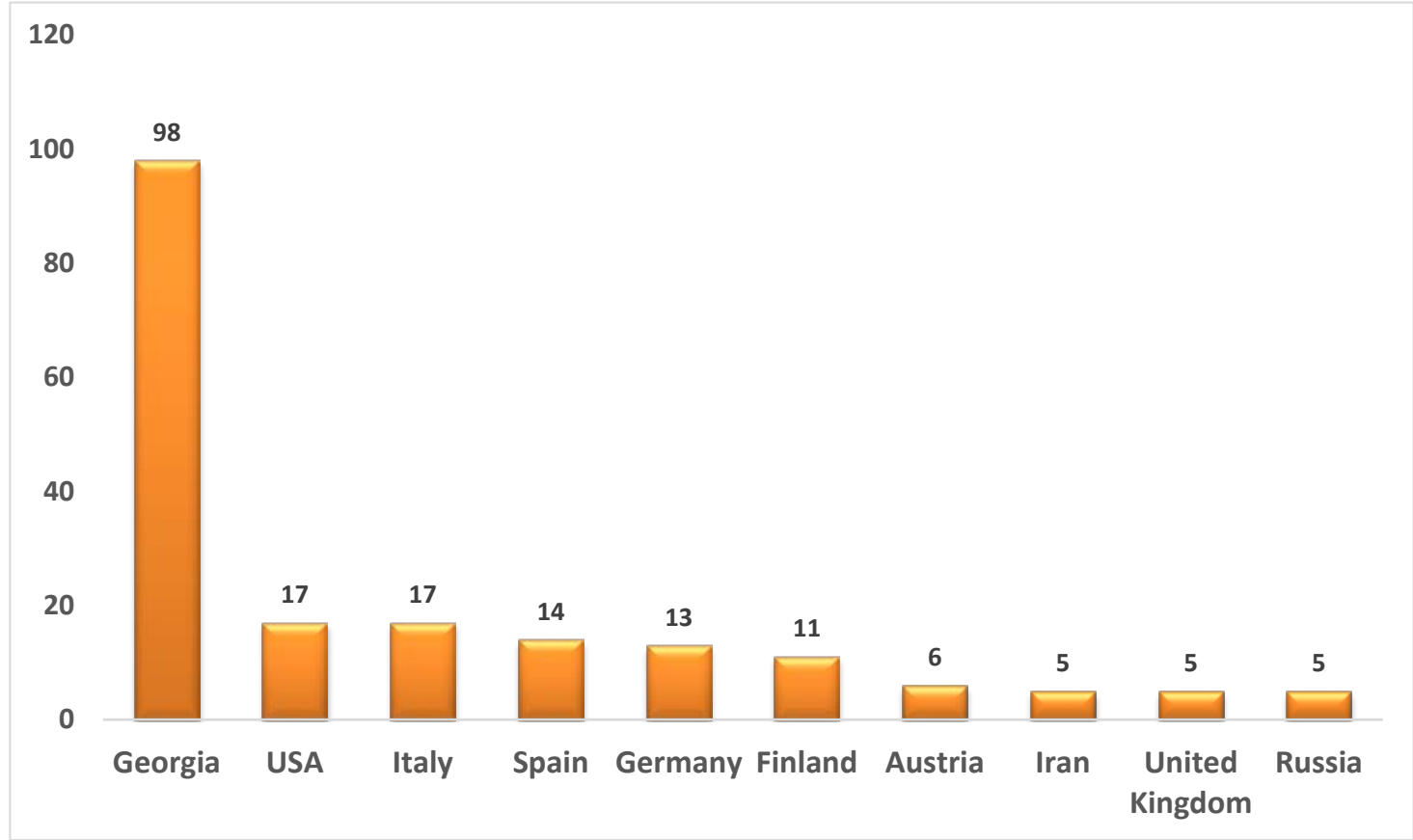

Fig. 5: International collaboration of the Republic of Georgia in the field of computer science.

International scientific collaboration of Georgia performed some similarities to Armenia (see Fig. 5). Here again the USA is the main scientific partner in the researched field, and here again the European direction is quite obvious. Although Georgia has joint publications with Russia, but their number is quite small (only 5).

Another distinctive feature among the Caucasus states is the cooperation with Iran in case of Azerbaijan and Georgia, while the cooperation of Armenia with Iran is quite limited to only 4 papers (it is not seen in the table, as we took the first 10 collaboration states).

As for the International scientific collaboration of the Baltic states, here the scientific preferences are much similar to each other. The three countries have accepted the European direction, which means that they are more actively collaborating with the other EU states. For all three countries, the USA is the second partner in the field. For Latvia and Estonia, Germany is the main collaboration country, while Estonian researchers prefer Sweden.

Fig. 6 details the collaboration pattern of Latvia. Interestingly, Russia is the forth in the list of partners of Latvia, while it is absent from the list of the first 10 collaborating countries of the other two Baltic states. 


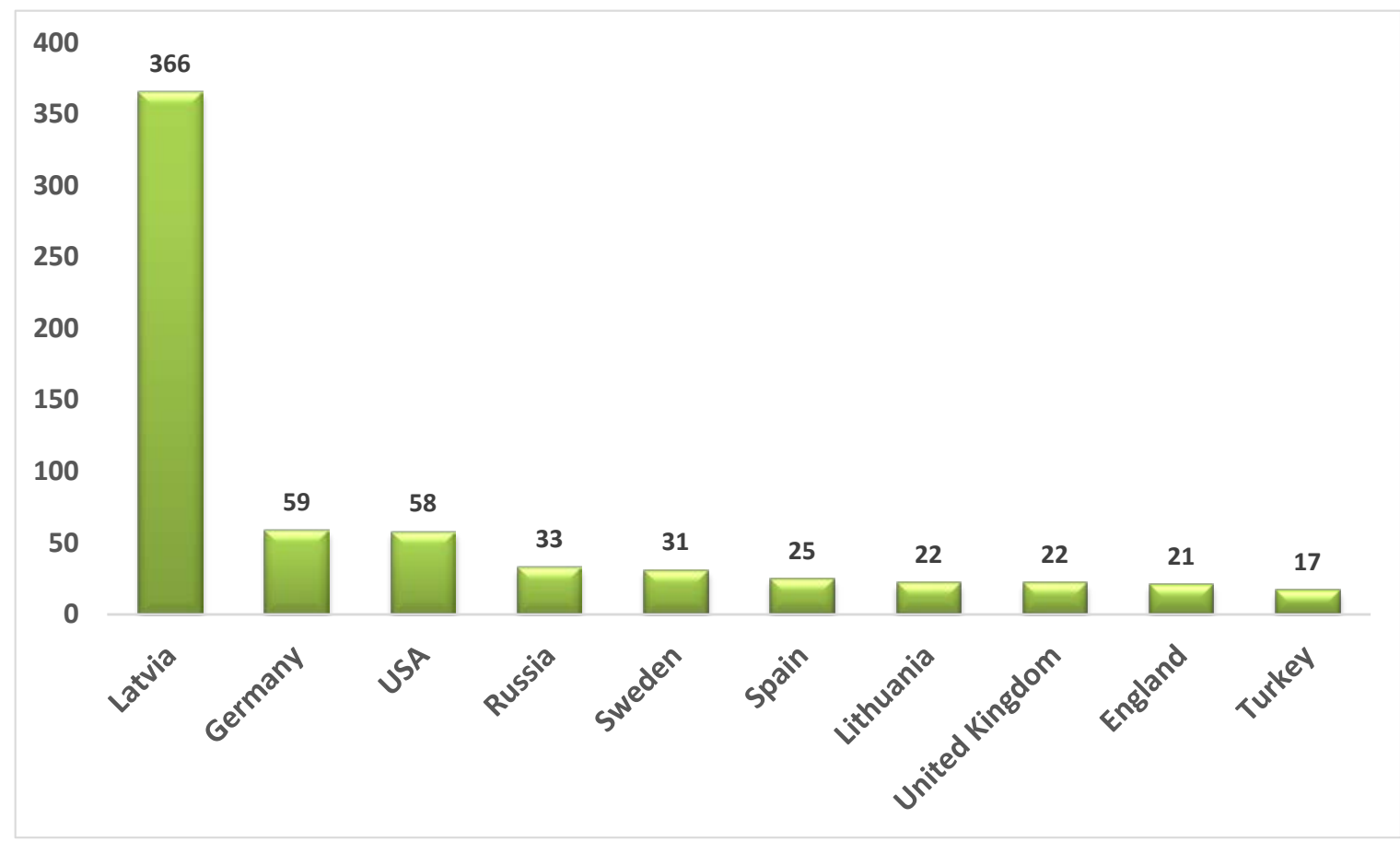

Fig. 6: International collaboration of Latvia in the field of computer science.

Fig. 7 presents the Lithuanian collaboration in computer science. Apart from general features identified before, China appeared to be among the collaboration countries with 31 joint publications.

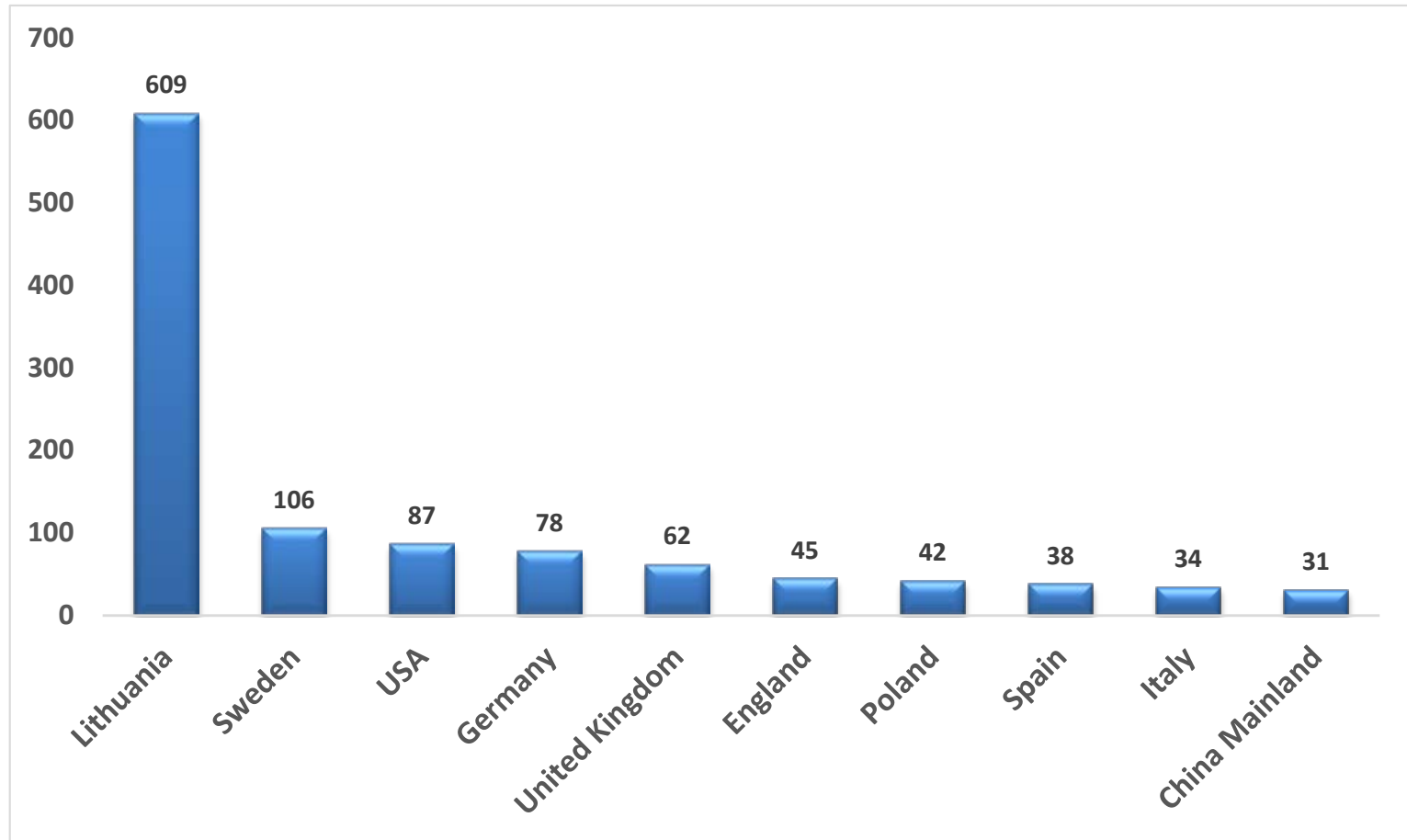

Fig. 7: International collaboration of Lithuania in the field of computer science. 
Fig. 8 presents the scientific collaboration of Estonia. The main difference from the other two Baltic states is the presence of Australia among the partner states.

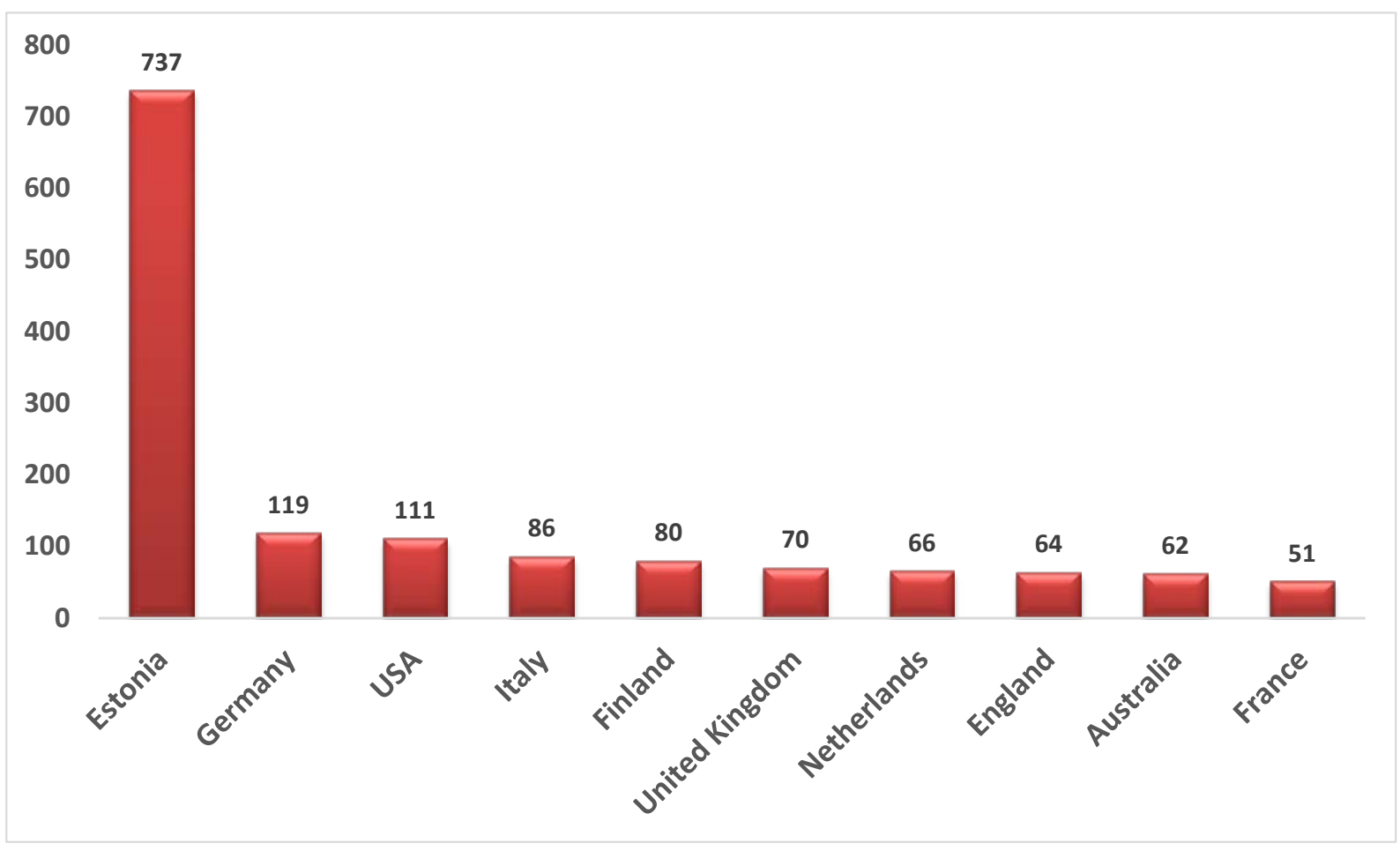

Fig. 8: International collaboration of Estonia in the field of computer science.

\section{Conclusion}

We studied the publications of the Baltic and Caucasus states in the field of computer sciences from the WOS database. We retrieved 7721 publications and also citations received by the 6 concerned states. Based on our findings, the Baltic states have nearly 3 times more publications on computer science than the Caucasus states. Among the Baltic states, the leading position is held by Lithuania, followed by Estonia and Latvia. In the Caucasus region, the leader is Azerbaijan, followed by Armenia and Georgia. Despite its leading position in the field of computer science during the Soviet times, Armenia was unable to maintain its position, while Lithuania, which was the forerunner among the Baltic states during the Soviet times, was able to keep its position.

We noticed a sharp increase in publications from the Baltic states after their accession to the EU. So, the EU accession of the Baltic states significantly affected the number of their publications and citations in the field of computer science.

As for the scientific collaboration, the countries studied showed some similar and also diverse behavior. The USA is an important partner for all 6 countries. The Baltic states, Armenia and Azerbaijan are actively collaborating with the EU member-states, while the European direction is not popular with Azerbaijan. The latter is quite actively working with Turkey, with which Azerbaijan has close political ties.

As for the post-Soviet countries, only Armenia and Latvia have a significant number of joint publications with Russia, while the joint Georgian-Russian papers in the field are only 5. 


\title{
References
}

[1] E. Tyugu, “Computing and Computer Science in the Soviet Baltic Region”, in History of Nordic Computing 2, Timo Järvi Petri Paju (Eds.), Springer, pp. 29- 37, 2009.

[2] U. Finardi, "Scientific collaboration between BRICS countries", Scientometrics, vol. 102, но. 2, pp. 1139-1166, DOI 10.1007/s11192-014-1490-5, 2015.

[3] M. Zitt, E. Bassecoulard and Y. Okubo, "Shadows of the past in international cooperation: collaboration profiles of the top five producers of science", Scientometrics, vol. 47, no. 3, pp. 627-657, 628-629, 2000.

[4] P. S. Nagpaul, "Exploring a pseudo-regression model of transnational cooperation in science”, Scientometrics, vol. 56, no. 3, pp. 403-416, 2003.

Submitted 28.02.2019, accepted 09.04.2019.

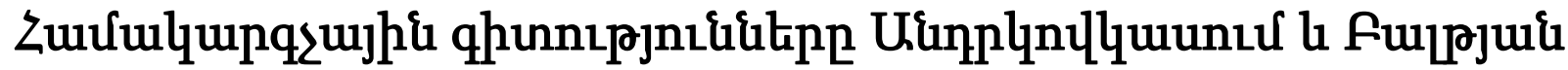

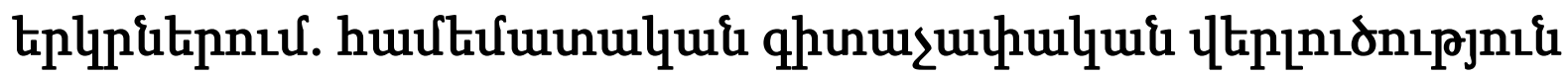

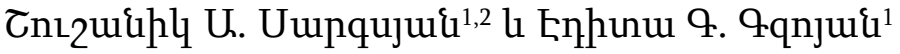

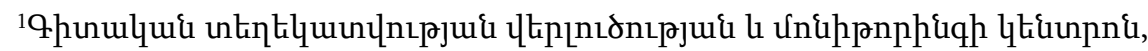

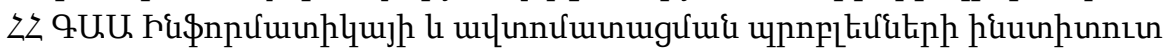

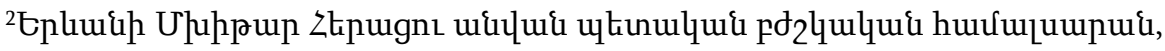 \\ $\mathrm{Fd}_{2}$ quilumi \$hqhluujh urfphni \\ e-mail: shushanik@ipia.sci.am
}

\section{U.ựnnนhnนu}

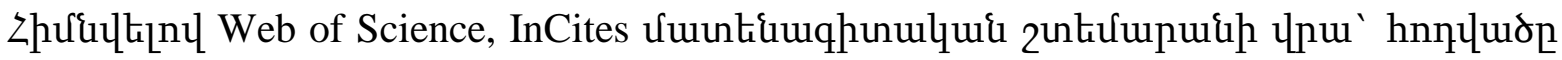

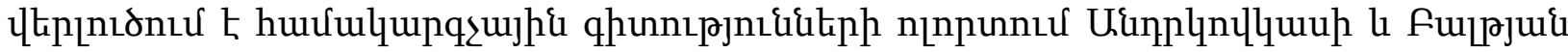

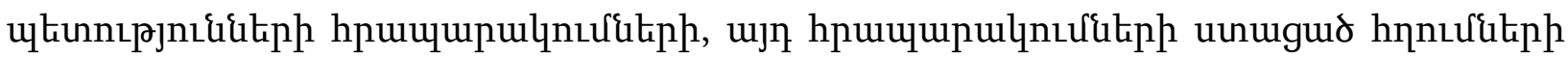

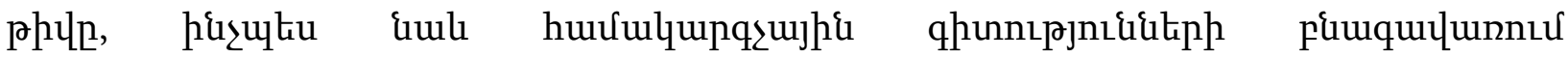

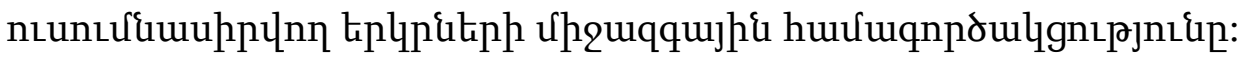

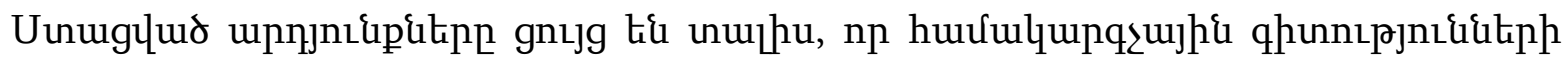

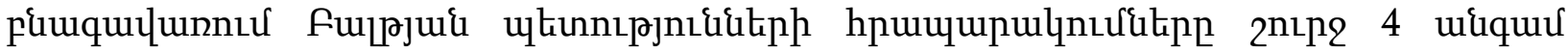

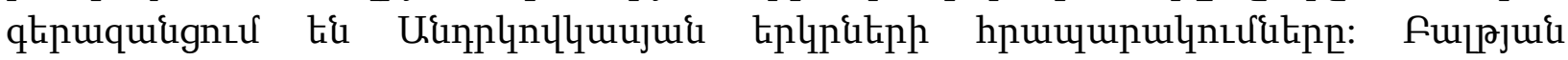

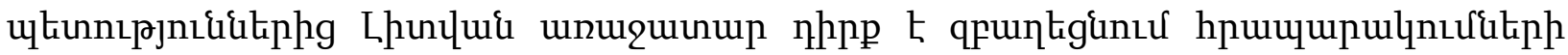

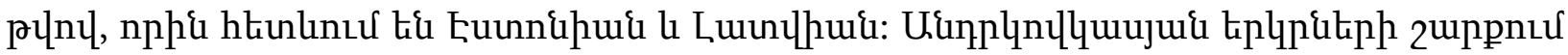

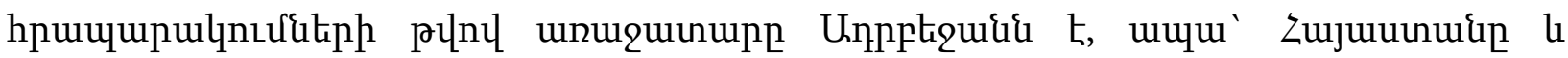

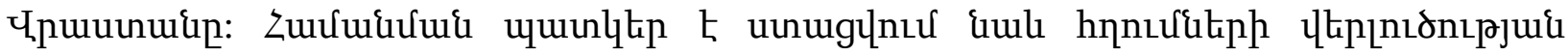

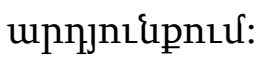




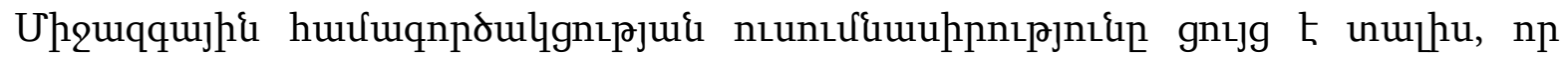

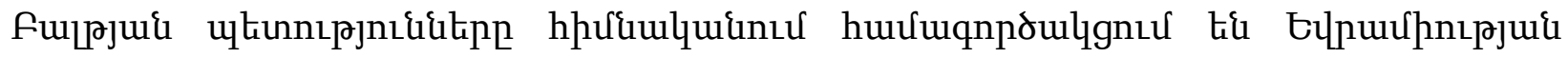

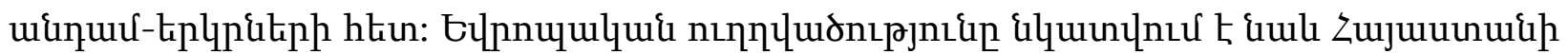

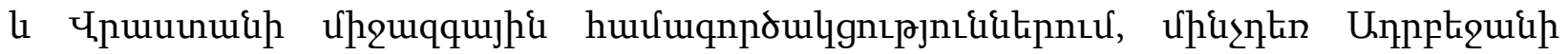

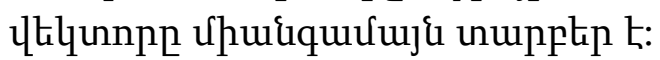

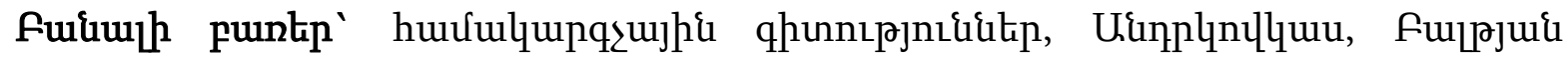

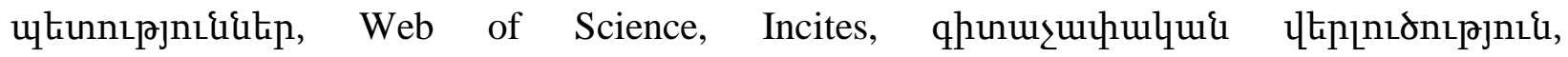

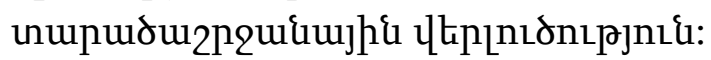

\title{
Компьютерные науки в Закавказье и странах Балтии: сравнительный наукометрический анализ
}

\author{
Шушаник А. Саргсян ${ }^{1,2}$ и Эдита Г. Гзоян ${ }^{1}$ \\ ${ }^{1}$ Центр анализа и мониторинга научной информации, \\ Институт проблем информатики и автоматизации НАН РА \\ ${ }^{2}$ Ереванский государственный медицинский университет им. Мхитара Гераци, \\ кафедра медицинской физики \\ e-mail: shushanik@ipia.sci.am
}

\begin{abstract}
Аннотация
Основываясь на библиометрические базы данных Web of Science, InCites, статья анализирует число публикаций и цитирований на эти публикации в сфере компьютерных наук в странах Закавказья и Балтии, а также международное сотрудничество вышеуказанных стран в сфере компьютерных наук.

Полученные данные показывают, что в сфере компьютерных наук число публикаций стран Балтии превышает аналогичный показатель стран Закавказья около 4 раз. Лидером по числу публикаций из стран Балтии является Литва, за которой следуют Эстония и Латвия. Первое место в Закавказье занимает Азербайджан, второе место - Армения, а третье - Грузия. Аналогичная картина складывается и при анализе числа цитирований.

Исследование международного сотрудничества показывает, что страны Балтии сотрудничают в основном со странами ЕС. Европейское направление международного сотрудничества наблюдается и в случае Армении и Грузии, в то время, как вектор международного сотрудничества Азербайджана совершенно другой.

Ключевые слова: компьютерные науки, Закавказье, страны Балтии, Web of Science, InCites, наукометрический анализ, региональный анализ.
\end{abstract}

